\title{
Using of synbiotic and garlic powder as alternatives to antibiotic on growth performance and carcass criteria of Japanese quails
}

\author{
Elsagheer M. A. ${ }^{a^{*}}$, Essa N. M. ${ }^{a}$, El-Sagheer M. ${ }^{b}$ \\ ${ }^{a}$ Department of Animal Production, Faculty of Agriculture, Al-Azhar University, Assiut, Egypt \\ ${ }^{b}$ Department of Poultry Production, Faculty of Agriculture, Assiut University, Assiut, Egypt
}

\begin{abstract}
This experiment was designed to evaluate the effects of synbiotic and garlic powder as alternatives to antibiotic on growth performance and carcass criteria of Japanese quails until 42 days of age. In a complete randomized block experimental design, a total number of 156 unsexed one-day-old Japanese quails were allocated randomly distributed into three equal groups; treatment group consisted of four replicates of 13 each. All birds were kept under the same managerial conditions. The first group (C) was fed the basal diet with antibiotic (Amoxicillin) 1g/kg diet and served as control, while the second (T1) and the third (T2) groups were fed the basal diets supplemented with synbiotic (PoultryStar ${ }^{\circledR}$ sol) and garlic powder (Allium sativum) at the level of $1 \mathrm{~g}$ and $20 \mathrm{~g} / \mathrm{kg}$ diet, respectively. The results indicated that birds fed diet supplemented with $1 \mathrm{~g}$ synbiotic/kg diet had significant $(\mathrm{P} \leq 0.05)$ higher body weight, daily body weight gain, feed consumption and feed conversion ratio as compared with $\mathrm{T} 2$ and $\mathrm{C}$ groups. Group $\mathrm{T} 1$ had no mortalities. Carcass, liver, gizzard and giblets percentages were significantly $(\mathrm{P}<0.05)$ higher in $\mathrm{T} 1$ group compared with other groups, while, the highest value $(\mathrm{P} \leq 0.05)$ of abdominal fat $\%$ was obtained in control one. From these results, it could be concluded that the supplementation of $0.1 \%$ synbiotic as an alternative to antibiotic in Japanese quails diets were highly recommended to obtain higher growth performance and carcass criteria.
\end{abstract}

Keywords: antibiotic, synbiotic, garlic, Japanese quails, performance.

*Corresponding author: Elsagheer M. A.,

E-mail address: mohammadHousien.4419@azhar.edu.eg 


\section{Introduction}

production to control disease, and as growth performance promoters to improve growth rate and feed conversion efficiency. However, due to problems of using antibiotics on birds' health and production such as residue in the final products, development of bacterial resistance, accumulation in poultry excretion with consequent environmental pollution (Edens, 2003), its use has been banned in many countries and has been severely limited, or will be eliminated, in many others in the near future via regulations or by initiatives driven by consumer concern. The synbiotic concept is: mixtures of probiotics and prebiotics that beneficially affect the avian by improving the survival and implantation of live microbial dietary supplements in the gastrointestinal tract, by selectively stimulating the growth and/or by activating the metabolism of one or a limited number of health-promoting bacteria, thus improving bird welfare (Gibson and Roberfroid, 1995). The use of synbiotic in poultry production encourages a healthy gut via certain possible mechanisms, such as enhancing the immune system (Hamasalim, 2016), lowering $\mathrm{pH}$, and increasing protective gut mucus (Nikpiran et al., 2013), creating an antimicrobial effect, increasing the digestibility of nutrients and enhancing nutrition performance (Awad et al., 2009). In previous studies conducted on poultry, it was reported that the use of Synbiotic enhances growth performance and carcass yield (Vahdatpour et al., 2011). Gibson and Roberfroid (1995) stated that the use of compounds that may have probiotic effects is a possible way to improve intestinal health and bird performance in the absence of antibiotic growth promoters. Allium sativum (garlic) supplements in poultry have been recognized for their strong stimulating effect on the immune system and the very rich aromatic oils enhance digestion of birds (Gardzielewska et al., 2003). The key active ingredient in garlic is a powerful plant chemical called allicin which rapidly decomposes to several volatile organosulphur compounds with bioactivities (Chang and Cheong, 2008). Garlic is used both as condiment and medicament, anticoagulant, antioxidant, hypolipidaemic, antihypertensive, antiageing, anti-platelet and heavy metal detoxifier (Agarwal, 1996; Marilym, 2001). The present study aimed to evaluate Japanese quail performance using synbiotic and garlic powder in order to find out the most suitable ones and their possibility as alternatives to antibiotics in quails production.

\section{Materials and methods}

This study was carried out at Poultry Farm, Department of Poultry Production, Faculty of Agriculture, Assuit University, Assuit, Egypt during the period from March 2018 to May 2018.

\subsection{Experimental design}

A total number of 156 unsexed, healthy, one-day-old Japanese quails were selected and randomly distributed into three equal groups. Each group included 4 replicates 
of 13 chicks each. The first group (C) was fed the basal diet with antibiotic (Amoxicillin) 1g/kg diet, while the second and the third groups (T1 and T2, respectively) were fed the basal diet supplemented with synbiotic (PoultryStar ${ }^{\circledR}$ sol) and garlic powder (Allium sativum) at the levels of $1 \mathrm{~g}$, and $20 \mathrm{~g} / \mathrm{kg}$ diet, respectively. The composition and analysis of the basal diet are shown in Table (1).

\subsection{Birds' management}

All birds were housed in floor pens at the same space (Dimensions of nest per replicate are Length $=70 \mathrm{~cm}$, Width= $35 \mathrm{~cm}$, Height $=40 \mathrm{~cm}$ ), using the straw as litter at $3 \mathrm{~cm}$ deepness, in open house under similar hygienic and normal environmental conditions with natural ventilation. All birds were vaccinated for Newcastle disease at 7, 18, and 28 day (B1 Type, LaSota Strain, Live Virus). Vaccine produced by International Company Wiesbaden, Germany (Intervet Company). Feed was available allover experimental period, with the same feeder space. Also, fresh tap water available all time through the normal waterers. The birds during the first week of age were exposed to the continuous lighting program (24 hour light per day), from two week to the end of experiment, the birds were exposed the lighting program of 23 hour light and one hour dark per day; which depend on natural light and exposed to artificial light by using incandescent lambs, 60 watt hanged at a level of $60 \mathrm{~cm}$ from the floor.

Table 1: The composition and proximate chemical analysis of the basal diet.

\begin{tabular}{|c|c|}
\hline Ingredients & $\%$ \\
\hline Yellow corn & 56.5 \\
\hline Corn Gluten $(60 \%)$ & 8.0 \\
\hline Soybean meal $(44 \% \mathrm{CP})$ & 30.0 \\
\hline Limestone & 2.1 \\
\hline Di-phosphate calcium & 0.6 \\
\hline Salt & 0.3 \\
\hline Oil & 2.0 \\
\hline Vitamins minerals mixture* & 0.3 \\
\hline DL - Methionin & 0.1 \\
\hline L-Lysine & 0.1 \\
\hline Total & 100 \\
\hline \multicolumn{2}{|c|}{ Calculated analysis $^{* *}$} \\
\hline Metabolizable energy $\mathrm{kcal} / \mathrm{kg}$ diet & 3020 \\
\hline Crude protein, $\%$ & 22.8 \\
\hline Crude fiber, $\%$ & 3.42 \\
\hline Ether extract, \% & 4.54 \\
\hline Calcium, $\%$ & 1.04 \\
\hline Available phosphorus, $\%$ & 0.45 \\
\hline Methionine and cystine, $\%$ & 0.9 \\
\hline Lysine \% & 1.1 \\
\hline
\end{tabular}

*Vitamins and minerals premix provided per kilogram of the diet: Vit A, 1000 IU; D3 2000 ICU; Vit E, $10 \mathrm{mg}$; Vit K, 1mg; B1, $10 \mathrm{mg}$; B2, $5 \mathrm{mg}$; B6, $1500 \mathrm{mg}$; B12, 10mg Pantothenic acid, $10 \mathrm{mg}$; Nicotinic acid, $30 \mathrm{mg}$; Folic acid, $1 \mathrm{mg}$; Biotin, $50 \mathrm{mcg}$; Chloride, $500 \mathrm{mg}$; copper, $10 \mathrm{mg}$; iron, $50 \mathrm{mg}$; Manganese, $60 \mathrm{mg}$; Zinc, $50 \mathrm{mg}$, and selenium, $0.1 \mathrm{mg}$. ** Calculated according to NRC (1994). 


\subsection{Experiment substances}

\subsubsection{Antibiotic (Amoxicillin)}

The antibiotic which used in this study (Amoxicillin) was provided by the manufacturing company El Nasr Pharmaceutical Chemical Company., Abu Zaabl, Egypt. It's composition as follow: 23g Amoxcillin Trihydrate and 20g Equivalent to Amoxcillin base.

\subsubsection{Synbiotic (PoultryStar ${ }^{\circledR}$ sol)}

The synbiotic used in this study (PoultryStar ${ }^{\circledR}$ sol) was provided by the manufacturing company BIOMIN Singapore. Supplier by BIOMIN GmbH, Austria. PoultryStar ${ }^{\circledR}$ sol is based on natural raw materials combing the beneficial effects of probiotic and prebiotic. The composition of Synbiotic is [ 900 gm Fructo- Oligosaccharides (Prebiotic), $100 \mathrm{gm}$ Blend of bacteria (Probiotic); Bacteria in blend: Enterococcus sp., Bifidobacterium sp., Pediococcus sp. and Lactobacilluc spp.; Product contains a minimum of $5 \times 10^{12}$ $\mathrm{CFU} / \mathrm{Kg}$ of blend of bacteria.

\subsubsection{Garlic powder (Allium sativum)}

The garlic (Allium sativum) used in this study was bought from a local market in raw form. Then, it was cut into smaller pieces and dried sufficiently in the sunlight. After drying, required amount of garlic was prepared by fine grinding and passing through $1 \mathrm{~mm}$ sieve.

\subsection{Parameters studied}

The live body weight (BW) of each replicate recorded to the nearest gram every week through the experimental period from one day to six weeks of age. Body weight gain was calculated by subtracting initial body weight from final body weight and then divided the result on the number of days to calculate daily body weight gain. Feed consumption of each replicate was recorded as a difference between accumulative weight of feed during the week and the weight of residual feed at the end of the week, and then divided the result on the period to calculate the daily feed consumption as follow: the feed consumption /bird = (Initial weight of feed - final weight of feed) / live birds' number during the period. Daily feed consumption /bird = the feed consumption /the period (days). Feed conversion ratio was calculated as the amount of feed ( $g$ ) required for producing one gram of body weight gain.

$$
\mathrm{FCR}=\frac{\text { Average of feed consumption }(\mathrm{g}) / \mathrm{bird} / \text { day }}{\text { Average of body weight gain }(\mathrm{g}) / \mathrm{bird} / \mathrm{day}}
$$

Dead chicks during the experimental period were recorded daily from 7 day of age to the end of experiment. Mortality rate was calculated for the entire experimental period and expressed as percentage.

Mortality rate $(\%)=\frac{\text { Number of dead birds of replicate }}{\text { Number of birds of replicate }} \times 100$

\subsection{Slaughter traits}

At the end of six weeks of age, six birds ( 3 males and 3 females) were randomly selected from each treatment, then weighted and slaughtered. After complete bleeding, birds were scaled, and then feather were picked by hand and 
eviscerated. Different organs (liver, heart, gizzard and giblets) were weighed and expressed as a percentage of carcasses. Also, the abdominal fat was separated, weighed and expressed as a percentage of carcasses.

\subsection{Statistical analysis}

The data obtained were subjected to statistical analysis using one-way ANOVA according the following model:

$\mathrm{Y}_{\mathrm{ij}}=\mu+\mathrm{T}_{\mathrm{i}}+\mathrm{E}_{\mathrm{iK}}$

Where; $Y_{i j}=$ an observation; $\mu=$ overall mean; $\mathrm{T}_{\mathrm{i}}=$ effect of treatment; $\mathrm{E}_{\mathrm{iK}}=$ random error. Differences among means of the experimental groups were testified for significance by Duncan's multiple range test (Duncan, 1955). Significant differences were considered to exist when $\mathrm{P} \leq 0.05$.

\section{Results and Discussion}

\subsection{Growth performance}

The effects of alternatives to antibiotic on growth performance (body weight, body weight gain, feed consumption, and feed conversion ratio and mortality rate) are shown in Table (2).

Table (2): The effect of alternatives to antibiotic on growth performance.

\begin{tabular}{|c|c|c|c|c|c|c|}
\hline \multirow{2}{*}{ Parameters } & \multirow{2}{*}{ Age } & \multicolumn{3}{|c|}{ Groups } & \multirow{2}{*}{ SEM } & \multirow{2}{*}{ Probability } \\
\hline & & $\mathrm{C}$ & $\mathrm{T} 1$ & $\mathrm{~T} 2$ & & \\
\hline \multirow{7}{*}{ Body weight (g) } & One day & 7.8 & 7.8 & 7.8 & 0.01 & 0.3664 \\
\hline & $1^{\text {st }}$ week & $32.6^{\mathrm{b}}$ & $33.7^{\mathrm{a}}$ & $30.8^{\mathrm{c}}$ & 0.04 & 0.0001 \\
\hline & $2^{\text {nd }}$ week & $85.3^{\mathrm{b}}$ & $89.9^{\mathrm{a}}$ & $81.6^{\mathrm{c}}$ & 0.32 & 0.0001 \\
\hline & $3^{\text {rd }}$ week & $123.6^{\mathrm{b}}$ & $131.6^{\mathrm{a}}$ & $123.8^{b}$ & 0.45 & 0.0001 \\
\hline & $4^{\text {th }}$ week & $172.5^{\mathrm{b}}$ & $185.9^{\mathrm{a}}$ & $172.7^{b}$ & 0.81 & 0.0001 \\
\hline & $5^{\text {th }}$ week & $220.0^{\mathrm{b}}$ & $252.6^{\mathrm{a}}$ & $222.9^{b}$ & 2.04 & 0.0001 \\
\hline & $6^{\text {th }}$ week & $238.7^{b}$ & $277.9^{a}$ & $239.7^{b}$ & 1.23 & 0.0001 \\
\hline \multirow{4}{*}{$\begin{array}{l}\text { Body weight gain } \\
\text { (g/bird/day) }\end{array}$} & $0-3$ week & $5.7^{\mathrm{C}}$ & $6.3^{\mathrm{a}}$ & $5.9^{\mathrm{b}}$ & 0.21 & 0.0039 \\
\hline & 4-6 week & $4.5^{\mathrm{b}}$ & $6.0^{\mathrm{a}}$ & $4.5^{\mathrm{b}}$ & 0.22 & 0.0002 \\
\hline & $0-5$ week & $6.3^{\mathrm{b}}$ & $7.2^{\mathrm{a}}$ & $6.3^{\mathrm{b}}$ & 0.19 & 0.0001 \\
\hline & $0-6$ week & $5.2^{\mathrm{b}}$ & $6.5^{\mathrm{a}}$ & $5.2^{\mathrm{b}}$ & 0.15 & 0.0001 \\
\hline \multirow{4}{*}{$\begin{array}{l}\text { Feed consumption } \\
\text { (g/bird/day) }\end{array}$} & 0-3 week & $12.7^{\mathrm{b}}$ & $13.1^{\mathrm{a}}$ & $12.7^{\mathrm{b}}$ & 0.61 & 0.0018 \\
\hline & 4-6 week & $22.6^{\mathrm{C}}$ & $25.3^{\mathrm{a}}$ & $23.7^{\mathrm{b}}$ & 0.37 & 0.0003 \\
\hline & $0-5$ week & $16.1^{\mathrm{c}}$ & $17.4^{\mathrm{a}}$ & $16.5^{\mathrm{b}}$ & 0.4 & 0.0001 \\
\hline & $0-6$ week & $18.5^{\mathrm{c}}$ & $20.4^{\mathrm{a}}$ & $18.4^{\mathrm{b}}$ & 0.28 & 0.0001 \\
\hline \multirow{4}{*}{$\begin{array}{l}\text { Feed conversion ratio } \\
\text { (g feed: } \mathrm{g} \text { gain) }\end{array}$} & $0-3$ week & $2.2^{\mathrm{a}}$ & $2.1^{\mathrm{b}}$ & $2.1^{\mathrm{b}}$ & 0.11 & 0.0041 \\
\hline & 4-6 week & $5.6^{\mathrm{a}}$ & $4.3^{\mathrm{b}}$ & $5.5^{\mathrm{a}}$ & 0.68 & 0.0001 \\
\hline & $0-5$ week & $2.6^{\mathrm{a}}$ & $2.4^{\mathrm{b}}$ & $2.6^{\mathrm{a}}$ & 0.09 & 0.0001 \\
\hline & $0-6$ week & $3.9^{\mathrm{a}}$ & $3.0^{\mathrm{c}}$ & $3.8^{\mathrm{b}}$ & 0.14 & 0.0001 \\
\hline Mortality rate (\%) & $0-6$ week & $0.9^{\mathrm{a}}$ & $0.0^{\mathrm{b}}$ & $0.7^{\mathrm{a}}$ & 0.51 & 0.0292 \\
\hline
\end{tabular}

a,b,c Means with different superscripts in the same column are significantly different $(\mathrm{P}<0.05) . \mathrm{C}=$ Control $(0.1 \%$ Amoxicillin $), \mathrm{T} 1=$ Synbiotic $(0.1 \%), \mathrm{T} 2=$ Garlic powder $(2 \%) . \mathrm{SEM}=$ Standard error of means.

\subsubsection{Body weight $(B W)$}

Data showed that the birds in $\mathrm{T} 1 \mathrm{had}$ significantly $(\mathrm{P} \leq 0.05)$ higher $\mathrm{BW}$ than those of other groups (C and T2) during the whole experimental period (1-42 day 
of age). Our results revealed that there were no significant differences $(\mathrm{P}>0.05)$ between $\mathrm{T} 2$ and control at $3^{\text {rd }}, 4^{\text {th }}, 5^{\text {th }}$ and $6^{\text {th }}$ weeks of age. The obtained results in agreement with the finding of Vahdatpour et al. (2011) who showed that the Japanese quails fed $0.1 \%$ synbiotic had the higher $(\mathrm{P}<0.05) \mathrm{BW}$ than those which fed control diet at 1-42 day of age. However, Tofan and Bolacali (2017) reported that the adding of synbiotic at levels $0.1,0.2,0.3$ and $0.4 \%$ had no significant effects $(\mathrm{P}>0.05)$ on $\mathrm{BW}$ for Japanese quails at 42 day old. While, Bonos et al. (2010) showed that the addition of prebiotic at $2 \mathrm{~g} / \mathrm{kg}$ diet for Japanese quails significantly $(\mathrm{P}<0.05)$ decreased the BW during the period of 142 day of age. The improvement in BW for quails fed diets with $0.1 \%$ synbiotic could be attributed to action of probiotic on intestinal microflora and increasing the digestibility, absorbability and utilize ability of different nutrients in gastrointestinal tract by probiotic product enzymes of cellulose, amylase and protease and the action of exogenous enzymes on improving nutrient digestibility and reduction of nitrogen and phosphorus (Bedford, 2000), thus improved BW.

\subsubsection{Body weight gain (BWG)}

Data of body weight gain (BWG) are presented in Table 2. During 0-3, 4-6, 0-5 and $0-6$ weeks of age, birds fed synbiotic (T1) had significantly higher $(\mathrm{P} \leq 0.05)$ BWG than those fed of Garlic powder diets (T2) or the control diet (C), while there were no significant differences $(\mathrm{P} \leq 0.05)$ between groups ( $\mathrm{T} 2$ and $\mathrm{C})$. Our findings are in agreement with the findings of Amer and Khan (2011), who stated that supplementation of probiotic to the feed diets at levels $0.5,1$ and $1.5 \mathrm{~g} / \mathrm{kg}$ diet for broilers, resulted in significantly higher BWG (8-42 days) than those of antibiotic $(0.5 \mathrm{~g} / \mathrm{kg}$ diet zinc bacteracin). However, El-Hammady et al. (2014) found that the broilers fed ration supplemented with antibiotic Neomycin (200 mg/kg diet), achieved significantly higher BWG than birds received different levels of probiotic (1, 1.5 and $2 \mathrm{~g} / \mathrm{kg}$ diet) or the control diet during 0-6 weeks of age. The increase in BWG for quails which fed diets supplemented with $0.1 \%$ synbiotic could be considered as probiotics have been used as a feed supplement in diet of poultry to enhance productive performance and immune responses (Higgins et al., 2007). In this regard the dietary supplementation of probiotic benefit the bird by stimulating appetite (Nahashon et al., 1992), stimulate the immune system (Koenen et al., 2004), produce the endogenous digestive enzymes, decrease $\mathrm{pH}$ and release bacteriocins (Rolfe, 2000), so improved BWG.

\subsubsection{Feed Consumption (FC)}

From data presented in Table (2), we can note that birds in $\mathrm{T} 1$ had significant $(\mathrm{P} \leq 0.05)$ higher $\mathrm{FC}$ as compared to those in other treatments during the whole experimental periods. Also, T2 had significant $(\mathrm{P} \leq 0.05)$ higher $\mathrm{FC}$ as compared to control group during 4-6, 0-5 and 0- 6 weeks of age, except during 0-3 weeks of age. The obtained results in agreement with Vahdatpour et al. (2011), 
who showed that FC in birds fed diets with $0.1 \%$ synbiotic was significant higher $(\mathrm{P} \leq 0.05)$ than birds which fed control diet for Japanese quails at 1-42 day of age. However, Kalsum et al. (2012) stated that there no significant differences $(\mathrm{P}>0.05)$ in $\mathrm{FC}$ for Japanese quails between treatments of $1 \mathrm{~g}$ probiotic and antibiotic (1 $\mathrm{g} / \mathrm{kg}$ diet zinc bacteracin). While, Tofan and Bolacali (2017) indicated that the adding of synbiotic at levels $0.1,0.2,0.3$ and $0.4 \%$ significantly decreased FC as compared to control for Japanese quails at 42day old. The improvement in FC as addition of Synbiotic may be due to the ability of the probiotic and prebiotic to stimulate the appetite of birds. In addition, it may be associated with the improved BWG of the supplemented birds (Nahashon et al., 1996). Hamasalim, (2016) indicated that the improvement in FC may be associated with synbiotic assistance in digestion and absorption.

\subsubsection{Feed conversion ratio (FCR)}

Data on feed conversion rate are presented in Table (2). During 4-6, 0-5 and $0-6$ weeks of age, the birds of group $\mathrm{T} 1$ had significantly $(\mathrm{P} \leq 0.05)$ better feed conversion ratio (FCR) than those of the other groups ( $\mathrm{C}$ and $\mathrm{T} 2)$. While, there are not significant $(\mathrm{P}>0.05)$ between $\mathrm{T} 1$ and T2 groups during 0-3 weeks of age. However, during 4-6 and 0-5 weeks of age, there are not significant $(\mathrm{P}>0.05)$ between $\mathrm{C}$ and $\mathrm{T} 2$ groups. During $0-6$ weeks of age, birds of T2 had significantly $(\mathrm{P} \leq 0.05)$ better $\mathrm{FCR}$ than those of the Group C. These results in agreement with Vahdatpour et al. (2011), who indicated that the birds fed synbiotic had the best $(\mathrm{P} \leq 0.05)$ FCR than birds which fed control diet for Japanese quails at 1-42 day of age. Also, Musaad et al. (2017) showed that the probiotic at levels of $1,2,3 \mathrm{gm} / \mathrm{kg}$ diet significantly $(\mathrm{P} \leq 0.05)$ improved FCR as compared with antibiotic (Neomycin) at 5-35 day of age. However, our data disagreement with Manafi et al. (2016), who stated that the FCR was significantly $(\mathrm{P} \leq 0.0001)$ improved by adding $0.05 \%$ antibiotic (bacitracin methylene disalicylate (BMD)) as compared to $0.1 \%$ probiotic (Bacillus subtilis) in diets for Japanese quails from 37 to 42 weeks of age. Moreover, El-Faham et al. (2018) showed that the broilers received colistin antibiotic (Colistix $\left.{ }^{\circledR}\right) 1 \mathrm{~g} / \mathrm{kg}$ diet had significantly better $(\mathrm{P} \leq 0.05)$ FCR than those of the group birds received probiotic (Lactobacillus acidophilus (BioBac-Lac $($ ) at $1 \mathrm{~g} / \mathrm{kg}$ diet during the period of 1-38 day of age. On the other hand, Kalsum et al. (2012) stated that there no significant $(\mathrm{P}>0.05)$ differences in FCR for laying Japanese quails at 150 day of age between treatments of $1 \mathrm{~g}$ probiotic $/ \mathrm{kg}$ (contain Lactobacilus fermentum bacteria) diet and antibiotic (50 $\mathrm{mg}$ zinc bactericin/kg diet). Khalil et al. (2007) fed Japanese quails on garlic powder in diets at level $1.6 \%$ and observed better FCR of birds as compared to control diet during the period of 2-8 weeks of age. In contrast, Yalcin et al. (2007) reported that FCR was not affected by adding of garlic powder in diets at levels 5 and $10 \mathrm{~g} / \mathrm{kg}$ diet for Japanese quails during the period of 9-21 weeks of age. The improvement in FCR for quails received Synbiotic in diets could be attributed to the action of 
microbial floras on alimentary tract which have considerable effect on health and performance of birds (Alkhalf et al., 2010). The author suggested that the better FCR in synbiotic group could be attributed to the effect of probiotic and prebiotic which improve absorption of nutrients and depressed harmful bacteria that cause growth depression.

\subsubsection{Mortality rate (MR)}

Data in Table (2) showed group T1 had no mortalities, while there were no significant $(\mathrm{P}>0.05)$ differences between $\mathrm{T} 2$ and $\mathrm{C}$ groups in MR \% at (0-6) weeks of age. These results in agreement with Amer and Khan (2011), who indicated that the adding of probiotic at levels $0.5,1$ and $1.5 \mathrm{~g} / \mathrm{kg}$ diet for broilers significantly $(\mathrm{P} \leq 0.001)$ reduced the MR as compared with antibiotic $(0.5 \mathrm{~g}$ zinc bactericin) at 842 day of age. In contrast, El-Hammady et al. (2014) explained that the MR\% for broilers was not differing significantly $(\mathrm{P}>0.05)$ among antibiotic (Neomycin) at level $200 \mathrm{mg} / \mathrm{kg}$ diet and probiotic at levels $1,1.5$ and $2 \mathrm{~g} / \mathrm{kg}$ diet during $0-6$ weeks of age. Also, Musaad et al. (2017) showed that the differences in MR were not significant $(\mathrm{P}>0.05)$ among treatments of antibiotic (20mg Neomycin $/ \mathrm{kg}$ diet) and probiotic ((Dexflor- PR) contain Lactobacillus bacteria) at levels of 1, 2, 3 $\mathrm{g} / \mathrm{kg}$ diet for broilers during the period of 5-35 day of age. No mortalities for Japanese quails resulted by adding of $0.1 \%$ Synbiotic may be due to the probiotics had positive effects on health and immune response, also, probiotics had the potential to reduce the risk of infection by pathogens and to eliminate the antibiotic resistance among pathogenic organisms (Griggs and Jacob, 2005), or may be due to the ability of Synbiotic to reduce enteric disease infection, through stimulating of the immune system (Sanders, 1999).

\subsection{Caracas criteria}

Data of carcass criteria are presented in Table (3). The differences in the percentages of dressed carcass, body organ weights (Gizzard, heart and giblets) were significant $(\mathrm{P} \leq 0.05)$ among all groups. Data revealed that quails in T1 had significant $(\mathrm{P} \leq 0.05) \quad$ higher percentages of carcass, liver, gizzard and giblets as compared to $\mathrm{T} 2$ and $\mathrm{C}$ groups while, the birds in T2 group had significant $(\mathrm{P} \leq 0.05)$ higher as compared to $C$ group. Data explained that there are not significant in heart percentage among all groups. The abdominal fat percentage in $\mathrm{T} 1$ and $\mathrm{T} 2$ were lower $(\mathrm{P} \leq 0.05)$ than those of the $\mathrm{C}$ group. The abdominal fat percentage in $\mathrm{T} 1$ group were lower $(\mathrm{P} \leq 0.05)$ than those of the $\mathrm{T} 2$ group. These results are in agreement with those of Chimote et al. (2009), who reported that supplementation of probiotic in diets (100g/ton feed) for Japanese quails during the grower period (1-24 day of age) significantly $(\mathrm{P} \leq 0.05)$ increased carcass percentage. As well as, El-Faham (2014), who showed that the percentages of liver, gizzard and giblets were higher $(\mathrm{P}<0.05)$ in probiotic treatment at level $1 \mathrm{~g} / \mathrm{kg}$ diet as compared to antibiotic $(1 \mathrm{~g} / \mathrm{kg}$ diet zinc bacteracin) for broilers at 32 day of age. In addition, Musaad et al. (2017) found that the differences in percentage heart for broilers were not significantly $(\mathrm{P}>0.05)$ 
among antibiotic (20 mg Neomycin $/ \mathrm{kg}$ diet) and probiotic ((Dexflor- PR) contain Lactobacillus bacteria) at levels of 1, 2, 3 $\mathrm{g} / \mathrm{kg}$ diet groups at 5 weeks of age. Also, Tofan and Bolacali (2017), who reported that the adding of synbiotic at levels 0.1 , $0.2, \quad 0.3$ and $0.4 \%$ significantly $(\mathrm{P} \leq 0.0001)$ decreased the abdominal fat for Japanese quails at 42 day old. On the other hand, Sahin et al. (2008) explained that the adding of Synbiotic in diets at levels of $0.5,1$ and $1.5 \%$ of Japanese quails had no significant effects on carcass weight during the period of 1-35 day of age. Also, Fathi et al. (2018) showed that the adding of $1 \mathrm{~g}$ probiotic $/ \mathrm{kg}$ diet for broilers at 7-38 day of age had no significant effects on giblets $\%$.

Table (3): The effect of alternatives to antibiotic on carcass, some body organs weights and abdominal fat percentages.

\begin{tabular}{|l|c|c|c|c|c|}
\hline \multirow{2}{*}{ Item } & \multicolumn{3}{|c|}{ Groups } & \multirow{2}{*}{ SEM } & \multirow{2}{*}{ Probability } \\
\cline { 2 - 5 } & $\mathrm{C}$ & $\mathrm{T}$ & T2 & & \\
\hline Live body weight (g) & $215.5^{\mathrm{b}}$ & $242.2^{\mathrm{a}}$ & $228.0^{\mathrm{ab}}$ & 1.7 & 0.0381 \\
\hline Carccass weight (g) & $182.7^{\mathrm{c}}$ & $211.1^{\mathrm{a}}$ & $195.5^{\mathrm{b}}$ & 1.8 & 0.0041 \\
\hline Dressing carcass (including giblets) (\%) & $84.4^{\mathrm{c}}$ & $87.2^{\mathrm{a}}$ & $85.0^{\mathrm{b}}$ & 0.43 & 0.0031 \\
\hline Heart (\%) & 0.8 & 0.8 & 0.8 & 0.11 & 0.0874 \\
\hline Liver (\%) & $1.5^{\mathrm{c}}$ & $2.5^{\mathrm{a}}$ & $1.8^{\mathrm{b}}$ & 0.52 & 0.0001 \\
\hline Gizzard (\%) & $1.3^{\mathrm{c}}$ & $1.6^{\mathrm{a}}$ & $1.4^{\mathrm{b}}$ & 0.04 & 0.0438 \\
\hline Giblets (\%) & $3.7^{\mathrm{c}}$ & $4.9^{\mathrm{a}}$ & $4.1^{\mathrm{b}}$ & 0.02 & 0.0001 \\
\hline Abdominal fat (\%) & $1.1^{\mathrm{a}}$ & $0.7^{\mathrm{c}}$ & $0.9^{\mathrm{b}}$ & 0.14 & 0.0239 \\
\hline
\end{tabular}

${ }^{a, b, c}$ Means with different superscripts in the same column are significantly different $(\mathrm{P}<0.05) . \mathrm{C}=\mathrm{Control}(0.1 \%$ Amoxicillin), $\mathrm{T} 1=$ Synbiotic $(0.1 \%), \mathrm{T} 2=$ Garlic powder $(2 \%)$. SEM= Standard error of means.

Concerning the effects of garlic powder, Mahmood et al., (2009) found that dietary garlic $(0.5 \%)$ did not significantly affect heart for broilers. Also, Raeesi et al. (2010) revealed that feeding garlic powder-supplemented diets to broilers led to better $(\mathrm{P} \leq 0.05)$ liver, gizzard and giblets percentages as compared to those at control diet without garlic. Our results disagreement with Horton et al. (1991), who showed that the adding of garlic powder in diets for broilers had no significant $(\mathrm{P}>0.05)$ effect on abdominal fat at 42 day of age. Also, Raya et al. (2014) showed that the adding of garlic powder at levels $1,2,3$ and $4 \%$ the diets for Japanese quails had no significant effect $(\mathrm{P}>0.01)$ on carcass, liver, gizzard and giblets percentages at 15-42 day of age. The positive effect of synbiotic on carcass quality may be attributed to the improvement of the bird's health and the more efficient utilization of the feed nutrients, according to Ferket, (2004). Also, it could be due to decreased proliferation of pathogenic bacteria, thus, the digestive tract remains healthy, functions more efficiently and more nutrients are available for absorption (Spring et al., 2000). The improvement in relative weights of liver, gizzard and giblets resulted by alternatives to antibiotic for quails may be due to the greater weight gain and live weight of the probiotic group compared with control group (Awad et al., 2009). Also, it may be attributed to the high values of carcass weight for quails received alternatives in 
their diets as compared to those in control one. The decrease of abdominal fat in alternatives groups (T1 and T2 groups) as compared to antibiotic group could be attributed to that inhibiting the absorption of dietary fat and fatty acid synthesis, and/or promoting fatty acid b-oxidation reduces abdominal fat deposition by decreasing the size and/or the number of abdominal adipose cells. The regulation of lipid metabolism to reduce the abdominal fat content based on dietary composition and feeding strategy, as well as elucidating their effects on the key enzymes associated with lipid metabolism, could facilitate the production of lean meat and help to understand the fat-lowering effects of diet and different feeding strategies (Fouad and El-Senousey 2014). From the obtained results, it can be concluded that the supplementation with of $1 \mathrm{~g}$ synbiotic/kg diet as an alternative to antibiotics in growing Japanese quails are recommended to obtain higher growth performance, improved feed conversion and lower mortality and abdominal fat.

\section{References}

Agarwal, K. C. (1996), "Therapeutic actions of garlic constituents", Medicinal Research Reviews, Vol. 16 No. 1, pp. 111-124.

Alkhalf, A., Alhaj, M. and Al-Homidan, I. (2010), "Influence of probiotic supplementation on blood parameters and growth performance in broiler chickens", Saudi Journal of Biological Sciences, Vol. 17 No. 3, pp. 219-225.
Amer M.Y. and Khan, S. H. (2011), "A comparison between the effects of a probiotic and an antibiotic on the performance of Desi chickens", Veterinary World Journal, Vol. 5 No. 3, pp. 160-165.

Awad, W. A., Ghareeb, K., AbdelRaheem, S. and Bohm, J. (2009), "Effects of dietary inclusion of probiotic and synbiotic on growth performance, organ weights, and intestinal histomorphology of broiler chickens", Poultry Science, Vol. 88 No. 1, pp 49-55.

Bedford, M. (2000), "Removal of antibiotic growth promoters from poultry diets: Implications and strategies to minimize subsequent problems", World's Poultry Science Journal, Vol. 56 No. 4, pp. 347-365.

Bonos E. M., Chriataki, E. V. and Florou-Paneri, P. C. (2010), "Performance and carcass characteristics of Japanese quail as affected by sex or mannan oligosaccharides and calcium propionate", South African Journal of Animal Science, Vol. 40 No. 3, pp 173-184.

Chang, K. J. and Cheong, S. H. (2008), "Volatile organosulfur and nutrient compounds from garlic by cultivating areas and processing methods", Federation of American Societies for Experimental Biology Journal, Vol. 22, pp. 1108-1112.

Chimote M. J., Barmase, B. S., Raut, A. S., Dhok, A. P. and Kuralkar, S. V. 
(2009), "Effect of supplementation of probiotic and enzymes on performance of Japanese quails", Veterinary World, Vol. 2 No. 6, pp. 219-220.

Duncan D. B. (1955), "Multiple range and multiple tests", Biometrics, Vol. 11, pp 1-42.

Edens, F. (2003), "An Alternative for antibiotic use in poultry probiotics". Revista Brasileira de Ciência Avícola, Vol. 5 No. 2, pp. 75-97.

El-Faham, A. I., Ali, N. G. M. and Hayam, M. A. A. (2014), "Effect of using some natural feed addition substitute antibiotic growth promoters on performance and blood parameters of broilers", Egyptian Poultry Science Journal, Vol. 34 No. 3, pp 735-750.

El-Faham, A. I., Ali, G. M. and Abdelaziz, M. A. M. (2018), "Assessment of some feed additives as anti-biotic alternatives, in relation to carcass characteristics and economic traits of broiler chickens", Egyptian Poultry Science Journal, Vol. 38 No. 2, pp. 709-723.

El-Hammady, H. Y., El-Sagheer, M., Hassanien, H. H. M. and Hassan, H. A. (2014), "Performance and carcass traits of broilers supplemented with probiotic or neomycin antibiotic", Egyptian Journal of Animal production, Vol. 51 No. 2, pp. 107114.

Fathi. M. A., Namra, M. M. M., Ragab,
M. S. and Aly, M. M. M. (2018), "Effect of dietary supplementation of bacteria as growth promoters on performance of broiler chickens", Egyptian Poultry Science Journal, Vol. 38 No.2, pp. 391-408.

Ferket, P. R. (2004), Alternatives to antibiotics in poultry production: responses, practical experience and recommendations, Nutritional biotechnology in the feed and food industries: Proceedings of Alltech's $20^{\text {th }}$ Annual Symposium, Kentucky, USA, pp. 56-67.

Fouad A. M. and El-Senousey, H. K. (2014), "Nutritional factors affecting abdominal fat deposition in poultry: a review", Asian-Australasian Journal of Animal Sciences, Vol. 27 No. 7, pp. 1057.

Gibson, G. R. and Roberfroid, M. B. (1995), "Dietary modulation of the human colonic microbiota: Introducing the concept of prebiotics", Journal of Nutrition, Vol. 125 No. 6, pp. 1401-1412.

Gardzielewska, J., Pudyszak, K., Majewska, T., Jakubowska, M. and Pomianowski, J. (2003), "Effect of plant-supplemented feeding on fresh and frozen storage quality of broiler chicken meat", Animal Husbandry Series of Electronic Journal Polish Agriculture University, Vol. 6 No. 2, pp. 12.

Griggs, J. P. and Jacob, J. P. (2005), "Alternatives to antibiotics for organic poultry production" Journal 
of Applied Poultry Research, Vol. 14 No. 4, pp. 750-756.

Hamasalim, H. J. (2016), "Synbiotic as feed additives relating to animal health and performance", Advances in Microbiology, Vol. 6 No. 4, pp. 288-302.

Higgins, J. P., Higgins, S. E., Vicente, J. L., Wolfeden, A. D., Tellez, G. and Hargis, B. M. (2007), "Temporal effects of lactic acid bacteria probiotic culture on Salmonella in neonatal broilers", Poultry Science, Vol. 86 No. 8, pp 1662-1666.

Horton, G. M. J., Fennell, M. J. and Prasad, B. M. (1991), "Effect of dietary garlic (Allium sativum) on performance, carcass composition and blood chemistry changes in broiler chickens" Canadian Journal of Animal Science, Vol. 71 No. 3, pp. 939-942.

Kalsum, U., Soetanto, H. and Sjofjan, O. (2012), "Influence of a probiotic containing Lactobacillus fermentum on the laying performance and egg quality of Japanese quails", International Journal of Poultry Science, Vol. 11 No. 4, pp. 311-315.

Khalil, H. A., Faten, A. M., Haiam, S. and Mady, M. E. (2007), "Efficacy of dietary garlic under hot weather in Japanese quail", Egyptian Poultry Science Journal, Vol. 27 No. 3, pp. 645-661.

Koenen, M. E., Kramer, J., Van Der
Hulst, R., Heres, L., Jeurissen, S. H. M. and Boersma, W. J. E. (2004), "Immunomodulation by probiotic lactobacilli in layer- and meat-type chickens", British Poultry Science, Vol. 45 No. 3, pp. 355-366.

Mahmood, S., Mushtaq-Ul-Hassan, M., Alam, M. and Ahmad, F. (2009), "Comparative efficacy of Nigella sativa and Allium sativum as growth promoters in broilers", International Journal of Agriculture and Biology, Vol. 11 No. 6, pp.775-778.

Manafi, M., Khalaji, S., and Hedayati, M. (2016), "Assessment of a probiotic containing Bacillus subtilis on the performance and gut health of laying Japanese quails (Coturnix coturnix Japonica)", Brazilian Journal of Poultry Science, Vol. 18 No. 4, pp. 599-606.

Marilym, L. (2001), "Effect of garlic on blood lipids in particles with coronary heart disease", American Journal of Clinical Nutrition, Vol. 34, pp 2100-3203.

Musaad, I. E., Kamal, A. M. and Mukhtar, M. A. (2017), "Response of broiler chicks to commercial dietary microbial probiotic (dexflorpr) as natural growth promoter alternative to antibiotics", World Journal of Pharmacy and Pharmaceutical Sciences, Vol. 6 No. 5, pp. 105-117.

Nahashon, S. N., Nakaue, H. S. and Mirosh, L. W. (1992), "Effect of direct-fed microbials on nutrient 
retention and parameters of single comb white leghorn pullets", Poultry Science, Vol. 72 No. 1, pp. 87.

Nahashon, S. N., Nakaue, H. S. and Mirosh, L. W. (1996), "Performance of Single Comb White Leghorn layers with a live microbial during the growth and egg laying phases", Animal Feed Science and Technology, Vol. 57 No. 1-2, pp. 25-38.

Nikpiran, H., Vahdatpour, T., Babazadeh, D. and Vahdatpour, S. (2013), "Effects of Saccharomyces cerevisiae, thepax and their combination on blood enzymes and performance of Japanese quails (Coturnix japonica)", Journal Animal Plant Science, Vol. 23 No. 2, pp. 369-375.

NRC, (1994), Nutrient Requirements of Poultry, (9 ${ }^{\text {th }}$ rev.)", National Research Council, National Academy Press, Washington, D.C., USA.

Raeesi, M., Hoseini-Aliabad, S. A., Roofchaee, A., Zare Shahneh, A. and Pirali, S. (2010), "Effect of periodically use of garlic (Allium sativum) powder on performance and carcass characteristics in broiler chickens", World Academy of Science, Engineering and Technology, Vol. 68, pp. 12131219.

Raya, A. H., Sherif, E., Rabie, M. H. and Bedair, H. F. (2014), "Effect of dietary supplementation with dried garlic and thyme on growth performance of Japanese quail", Journal of Animal and Poultry Production, Vol. 5 No. 2, pp. 73-85.

Rolfe, R. D. (2000), "The role of probiotic cultures in the control of gastrointestinal health", The Journal of nutrition, Vol. 130 No. 2, pp. 396-402.

Sahin, T., Kaya, I., Unal, Y. and Elmali, D. A. (2008), "Dietary supplementation of probiotic and prebiotic combination (Combiotics) on performance, carcass quality and blood parameters in growing quails", Journal of Animal and Veterinary Advances, Vol. 7 No.11, pp. 1370-1373.

Sanders, M. E. (1999), "Probiotics", Food Technology, Vol. 53 No. 1, pp. 67-77.

Spring, P., Wenk, C., Dawson, K. A. and Newman, K. E. (2000), "The effects of dietary mannanoligosaccharides on cecal parameters and the concentrations of enteric bacteria in the ceca of salmonella challenged broiler chicks", Poultry Science, Vol. 79 No. 2, pp. 205-211.

Tofan, T. and Bolacali, M. (2017), "Effects of dietary addition of synbiotic on the performance, carcass traits and serum parameters of Japanese quails", Revista Brasileira de Zootecnia, Vol. 46 No. 10, pp. 805-813. 
Vahdatpour, T., Nikpiran, H., Yalcin, S., Ilyas, O., Adnan, S. and Babazadeh, D., Sina, V. and Ali, M. Yalcin, S. (2007), "The effect of (2011), "Effects of Protexin ${ }^{\circledR}$, dietary garlic powder on Fermacto ${ }^{\circledR}$ and combination of them performance, egg traits and blood on blood enzymes and performance serum cholesterol of laying quails", of Japanese quails (Coturnix Japonica)", Animal

of Biotechnology Research, Vol. 2 No. 3, pp. 283-291. Asian Australasian Journal of Animal Sciences, Vol. 20 No.6, pp. 944-947. 